\title{
The Effect of Cooperative Learning, Motivation and Information Technology Literacy to Achievement
}

\author{
Dwi Sulisworo ${ }^{1}$, Fadiyah Suryani ${ }^{2}$ \\ Physics Education, Ahmad Dahlan University \\ Jl. Kapas No 9, Yogyakarta 55164, Indonesia \\ 1email: dwi@uad.ac.id; 2 email: fadiyah.suryani@yahoo.com \\ Doi:10.5296/ijld.v4i2.4908 URL: http://dx.doi.org/10.5296/ijld.v4i2.4908
}

\begin{abstract}
The weakness of student understanding on physics (or science in general) at high school is one reason of the low of sciences research achievement in the higher education. In other words, the achievements and motivation of high school students in science learning will influence the advances in science. The aim of this research is to determine the effect of motivation, IT literacy and cooperative learning strategies to learning achievement of high school students. This research used two stay-two stray approach as cooperative learning model. The statistical analysis used ANCOVA with motivation and IT literacy as covariates. The result showed that learning strategy affected the learning achievement. Motivation could be used to explain the learning achievement, but not for IT literacy.
\end{abstract}

Keyword: motivation, literacy, cooperative learning, education, achievement

\section{INTRODUCTION}

The low science literacy in Indonesia cannot be separated from the quality of teachers, facilities and the less instructional strategies used by teachers. Surya states the teacher quality gap. Teachers of science and mathematics in various cities and districts in Indonesia have differences quality (Surya, 2010). There is a quality and skill gap between teachers in large cities and rural areas, especially in disadvantaged areas. In many cases, science teachers focus on concepts contained in the book. Science teachers still tend to retain the sequences in the book, regardless of the suitability of the student-learning environment. This makes learning ineffective, because the students are not responding to the subject matter and tend to cause boredom (Latifah, 2011). The learning quality improvement has not given a significant result, because the teachers still do not have sufficient skills in using learning models, so the day-to-day learning in schools still use the same strategy, i.e. direct lesson teaching strategy (Darliana, 2011).

Technology and science development influence on new opportunities in strategies and methods of learning, including the learning of science in secondary schools (Sangrà \& González-Sanmamed, 2010) (Nethercott, Marianti, \& Hunt, 2010). Constructivism paradigm as a paradigm that can give more opportunities to students for better understanding the knowledge in a variety of perspectives gives many possibilities. Learning approach that more centered on the learner (student centered learning) has been studied more intensively to improve the learning quality (Sahin, 2010). The expectation of this approach is that learning activities can be managed and directed independently by students (Ogawa, 2011) to achieve the learning goal (self-regulated learning). The fruitful learning model was developed by utilizing 
a variety of learning resources in order to provide a better learning environment (Gatch, July 2010).

The promoting of learning process improvement that more students centered in the classroom is very important in order to improve student motivation to learn science better. Teachers should enhance their ability to develop learning material that appropriate to student characteristics to provide opportunities of conducting meaningful learning (Roksa \& Potter, 2011). On the other hand, the penetration rate of mobile Internet use among teens should be taking into account. The fact indicates that students have high IT literacy as internet generation. Probably there is a skill gap between teacher and student in the IT literacy. This situation will affect the capability of teacher to arrange better learning environment for student to learn science. The problem on student motivation in this phenomenon will contribute to student learning achievement. Thus, the purpose of this research is to develop an appropriate learning strategy on the science learning in the senior high school, to know whether motivation can affect the learning achievement or not, and whether the IT literacy can affect the learning achievement on science learning.

\section{LITERATURE}

\section{Cooperative Learning}

Cooperative learning is not just activity on students grouping or giving them the group task. An activity becomes cooperative learning when the learning environment is oriented to provide a mutually supportive activity between each student to each other. In this activity, students grow together in giving meaning to the contextual phenomena. Cooperative learning has some important elements that characterized by positive interdependence, individual accountability, interaction each other, social skills, small groups and group process. Cooperative learning model is one learning model that promotes learning to know, learning to do, learning to be and learning to live together. This learning model can help students in enhancing students' positive attitudes to learn physics and can reduce or even eliminate student anxiety experienced when they learn physics. Interactions in groups give possibilities for students to adapt and to accept different ability and background of other students (Wyk, 2012). In addition, peer relationships are very important and cannot be underestimated. The peer encouragement to achieve better academic achievement not only foster well student motivation but also make students ready to work, and be attentive during learning and enhance the thinking ability (Hamid, Zakaria, \& Islam, 2012).

\section{Cooperative Learning: Two Stay-Two Stray}

Two Stay-Two Stray (TS-TS) is one of types of cooperative learning model. Difference to the other type of cooperative learning, the structure of Two Stay-Two Stray provides opportunities to submit work or information to the other groups. The sharing activities familiarize students to respect the each other opinions. Student can learn to express their opinions to others. Recognition of the other student opinion can enhance self-confidence and motivate the students to express their ideas or opinions. Students feel their existence are trusted and valued because each member has very important role and task in the implementation of inter-group opinion sharing. These interactive situations occur because the group cannot solve the task sharing opinions without the good cooperation between group members.

In addition, the presence of friends in a group can lead to mutual motivation in learning; they can help each other to overcome difficulties, mutual respect, ideas or opinions, as make the students well prepared for the task, and be attentive during learning. Using this learning model, student not only become more independent, not rely on the teacher, but also this model give encouragement to think and to participate actively in learning. This one model promote 
students to dare to ask and argue, so hopefully the physics learning process become more meaningful and able to nurture students' critical thinking skills.

The implementation of TS-TS divides students into four groups. The advantages using this way is students easily split into pairs, more ideas raised and more tasks solved rather than in two or three groups. The structure of TS-TS provides an opportunity for the group to present the results and information with other groups. The systematic implementation of TS-TS is:

1. Students work in groups consist of 4 members;

2. Once completed, the two members of each group leave their group and each leaved member visit (stray) to another difference group.

3. Two students who stay in their group are in the charge to explain their results to the guests from two difference groups.

4. Students who visit back to their own groups and then report their findings from other groups;

5. Each group matches and discusses their work with the result of the other group that visited.

Based on the steps above, it can be formulated that the implementation of TS-TS consists of three main stages, i.e. the first step is to work in own group, the second step is to share group opinion to the other groups, and the third step is to report the result from the other groups within own group.

\section{Motivation}

Motivation is an important factor in the student learning process (Zimmerman, 2000). According to the theory of motivation, expectations of success relate to three factors, i.e.: how student gives attribution to previous successes and failures, how student interprets their competence, and how student maintains self-esteem. This situation is related to how the student shows his/ her performance when he/ she as an individual interacts with the learning environment including learning material during the process. The level of student confidence whether he/ she can accomplish the task well or not determine student success (Ryan \& Deci, 2000).

The attribution theory explained that the motivation is influenced by the causal stability of student attributions the past (Weiner, 1972) (Graham, 1991). When students can explain why they succeeded or failed to accomplish tasks, they will have better confidence to do better in the future task. In this research, if students felt comfort and able to do well on their tasks, then they would likely more success when they were measured their performance.

Using the attribution theory related to the causal stability, motivation can predicted the learning success. Students who provide stable and constant attribution to their learning experiences will tend to unmanageable. On the contrary, if the attribution is unstable and temporary, then students were to be controlled. The self-efficacy concept closely relate to attribution theory. This theory assumes that the way on how people define competencies will affect their interpretation of the learning outcomes and future motivation actions and future learning interactions (Schunk, 1991). Students who consider competence as acquired skills tend to evaluate their ability to improve their capability. Students who consider competence as the inherent ability tend to evaluate by comparing their ability to the other student success. Consequently, when they frustrated, good students often choose to evaluate the process and the used strategies; they will more to be ready for the new challenge to expand their knowledge. On the other hand, students who see the competencies is inherent, to save their pride, they often choose to put small effort or select the easier task so they can attribute the failure as a lack of effort rather than lack of their inherent ability. 


\section{IT Literacy}

The concept of IT literacy coincided with the development of information and computer technology (ICT). The definition of IT literacy is quite diverse which explains the specificity of the general concept of literacy (Kapitzke, 2003) (Tuominen, Savolainen, \& Talja, 2005). IT literacy is an individual's ability to recognize information, find out when using the ability, and ability to analyze information effectively. Information literacy is increasingly important in the contemporary environment due to rapid of technological changing. Information literacy skills related to information technology, but it has broader implications for the individual, the education system, and society. Nowadays, IT literacy has become a basic requirement for individuals to be able to learn effectively and continuously in various fields of science and learning environment (Bruce, 1999). Computer literacy is a prerequisite to the information literacy development. Computer literacy generally refers to the ability to use applications software that runs on the computer. The definition of computer literacy is a having a basic understanding of what a computer is and how using it as a resource. Requirements for computer literacy is vary, but may include an understanding of the fundamentals of hardware, computer systems and applications related to the relevant peripherals (Bruce, 1999).

\section{METHODOLOGY}

The approach of this research is quantitative research. Subjects of this research activity were students of senior high school. The sampling technique was purposive cluster sampling which was to find the relevant student grade. The research method was quasi-experimental which the learning strategy was a considered factor. The learning strategy used on the treatment group was TS-TS strategy as one type of cooperative learning model. The statistic technique used in this analysis was the ANCOVA. The independent variables as a covariate are motivation and IT literacy.

There are two kinds of the instrument validation. The instruments that made and used by other researchers (instrumental motivation and student response) and the instrument developed for this study (learning achievement instrument). For the instrument that been used by other researchers, it was not needed to be tested for its validity and reliability. However, for the self-developed instrument, it was tested. In addition, the construct validity used expert judgment technique. Validity test used Pearson correlation method which alpha equal 5\%. While the reliability test used split half which alpha equal $5 \%$.

\section{RESULT AND DISCUSSION}

The descriptive statistics result shown in the following table 1. From the table 1, from both groups, controlled group and treatment group have the same number of participants (36 students). The mean of learning achievement (78.19) for treatment group (cooperative learning classroom) are higher than one for conventional learning (69.72). The standard deviation of cooperative learning and conventional learning are 73.96 and 11.25 respectively. Based on the standard deviation of both groups, the learning achievement of students who learn on cooperative learning was more homogeny (STD 8.8) rather than students who learn on conventional learning (STD 11.95). The difference result between both groups needs deeper further analysis whether it was statistically significantly different or not.

\section{Table 1. Descriptive Statistics}

Dependent Variable: Learning achievement
\begin{tabular}{|c|c|c|c|}
\hline Learning strategy & Mean & Std. Deviation & N \\
\hline Conventional Learning & 69.7222 & 11.94897 & 36 \\
Cooperative Learning & 78.1944 & 8.79552 & 36 \\
Total & 73.9583 & 11.25684 & 72 \\
\hline
\end{tabular}


In this research, the model used for the Sum of Square is a Type III where there are no assumptions before the process, whether covariate or treatment that comes first into the equation/model. So that, the hypothesis was tested twice for two purposes: (1) to determine the linear relationship between covariate and the response variable, and (2) to determine the differences effect between the treatment variable and response variable. Table 2 showed the result of this analysis.

Table 2. Tests of Between-Subjects Effects

Dependent Variable: Learning achievement

\begin{tabular}{|l|r|r|r|r|r|}
\hline Source & $\begin{array}{c}\text { Type III Sum } \\
\text { of Squares }\end{array}$ & df & Mean Square & \multicolumn{1}{c|}{ F } & \multicolumn{1}{c|}{ Sig. } \\
\hline Corrected Model & $7610.804(\mathrm{a})$ & 3 & 2536.935 & 124.461 & .000 \\
Intercept & 2256.963 & 1 & 2256.963 & 110.726 & .000 \\
MOTIVE & 6267.302 & 1 & 6267.302 & 307.471 & .000 \\
LITERASC & 52.189 & 1 & 52.189 & 2.560 & .114 \\
STRATEGY & 1282.888 & 1 & 1282.888 & 62.938 & .000 \\
Error & 1386.071 & 68 & 20.383 & & \\
Total & 402825.000 & 72 & & & \\
Corrected Total & 8996.875 & 71 & & & \\
\hline
\end{tabular}

a R Squared $=.846$ (Adjusted R Squared $=.839$ )

Using significance level $5 \%$, from table 2 , there are some interesting discussions on the findings. The first is that the model used in this analysis gave a good explanation to the phenomenon with both views on the significance of the corrected model, which is smaller than 0.05 with $F$ value equals 124.46 and $\mathrm{R}$ Squared value equals 0.846 or $84.6 \%$. The other result is that motivation was a predictor. Motivation can predict and explain the learning achievement seen on its significant effect with F value equals 241.85 . On the contrary, IT literacy cannot be used as a predictor to explain the learning achievement because it did not have a significant effect $(0.114)$ which this value were greater than 0.05 .

Based on the statistical analysis, the result showed that learning strategy had significant effect to the physics learning achievement. The cooperative learning, Two Stay Two Stray in this case, has better strategy to improve student achievement on physics learning rather than the conventional strategy. This finding is parallel to the learning theory that mentioned previously in the theoretical background. It means also that, teacher should understand this strategy to promote an alternative way on physics learning especially for senior high school.

From this research, motivation has effect or influence on student learning achievement. There is a tendency that the better the student's motivation, it can be estimated that he/ she will have a good learning achievement. According to the motivation theory, the expectations of success related to three factors: how students give attribution to the successes and failures of the previous activities, how students interpret their competence, and how students maintain their self-esteem. The situation is related to how the students show their performance when individuals interact with the learning materials and environment during the learning process. The confidence level of student whether he/ she can accomplish well of their task well or not will determine the student's success.

The attribution theory can explained that the stability and the causality of the attribution in the previous activities in the past influenced motivation. Related to the stability, these following sentences explain it. Students who feel the failure or success caused by something that stable like individual inability would tend to be less successful in the next task of in the future. On the contrary, students who saw the cause was something unstable like due to lack of 
effort will be more successful in the next task. While related to causality, students who see the locus of success was from internal will be more successful in the next task; and the vice versa.

The self-efficacy concept has a close relation to the causal stability concept. This concept can explain how students give the perception of their competence. When student feels that competencies come from something stable such as talent, he/ she will tend to be less successful for the next learning activity. Instead of student who feels to able to acquire the competence, he/ she will tend to able to increase learning performance in the next activity. Deeper analysis and study related to the motivation concept on new learning environment is very important for further arrangement. Teacher can use the motivation map of the student as the basis for motivation attribution development.

From this research, the results revealed that the students' IT literacy did not have a significant effect on learning achievement. There are several possibilities to explain this phenomenon. There was likely the paradox thing. Theoretically, students who have good IT skills or literacy will be able to search information better from more diverse and complete of relevant physics learning materials. However, this assumption did not exist. Should be, there were a reason to explain it. Consequently, the first lack should be no interaction between student's activity on physics learning at school and student's activity during information technology usage. It means that students take the advantage of information technology not to enhance the physics understanding but outside one. Deeper analysis revealed that students are reluctant to use information technology as learning resources because the limitation of physics material in mother's language in cyberspace which relevant to school activity. The second, teachers might not yet reveal the importance of information technology, especially information on the internet as an alternative physics learning resources. The lack of this skill caused teachers relatively did not push to use information technology on learning.

\section{CONCLUSION}

The low science literacy in Indonesia cannot be separated from the quality of teachers, facilities and the less instructional strategies used by teachers. The learning quality improvement has not given a significant result, because the teachers still do not have sufficient skills. The promoting of learning process improvement that more students centered in the classroom is very important in order to improve student motivation to learn science better. Learning strategy had significant effect to the physics learning achievement. The cooperative learning, Two Stay Two Stray in this case, has better strategy to improve student achievement on physics learning rather than the conventional strategy. Motivation has effect or influence on student learning achievement. There is a tendency that the better the student's motivation, it can be estimated that he/ she will have a good learning achievement. However, the students' IT literacy did not have a significant effect on learning achievement.

\section{ACKNOWLEDGEMENT}

This paper is part of the research on learning strategy and its implementation using e-learning or mobile learning supported by Directorate General of Higher Education through Postgraduate Research Grant (Hibah Penelitian Tim Pascasarjana) for Year 2013.

\section{REFERENCE}

Bruce, C. S. (1999). Workplace experiences of information literacy. International Journal of Information Management, Vol 19, 33-47.

Darliana. (2011, July 6). Peningkatan pembelajaran IPA. Retrieved February 18, 2012, from Penyelesaian Masalah Peningkatan Pembelajaran IPA: http://pipabdg.blogspot.com/2011/06/bagaimana-meningkatkan-mutu_16.html 
Gatch, D. B. (July 2010). Restructuring Introductory Physics by Adapting an Active Learning Studio Model. International Journal for the Scholarship of Teaching and Learning, Vol 4 No. 2 .

Graham, S. (1991). A review of attribution theory in achievement contexts. Educational Psychology Review, Volume 3, Issue 1, 5-39.

Hamid, D. T., Zakaria, N., \& Islam, M. R. (2012). Implementation of an Online Collaborative Learning through Grid Portal Technology. 3rd International Conference on e-Education, e-Business, e-Management and e-Learning (pp. 35-42). Singapore: IPEDR vol.27, IACSIT Press.

Kapitzke, C. (2003). (In)formation literacy: A positivist epistemology and a politics of (out)formation. Educational Theory, Vol 53 No 1, 37-53.

Latifah, N. (2011, March 6). Noor Latifah's Blog. Retrieved February 16, 2012, from Penelitian TIndakan

Kelas: http://latifah04.wordpress.com/2008/04/03/penelitian-tindakan-kelas/

Nethercott, K., Marianti, R., \& Hunt, J. (2010). Gender Equality Results in ADB Projects. Manila: Asian Development Bank.

Ogawa, A. (2011). Facilitating Self-Regulated Learning: An Exploratory Case of Teaching a University Course on Japanese Society. International Journal of Teaching and Learning in Higher Education, Vol 23 No 2 , pp. 166-174.

Roksa, J., \& Potter, D. (2011). Parenting and Academic Achievement: Intergenerational Transmission of Educational Advantage. Sociology of Education, Vol 84 No 4 , pp. 299-321.

Ryan, R. M., \& Deci, E. L. (2000). Intrinsic and Extrinsic Motivations: Classic Definitions and New Directions. Contemporary Educational Psychology 25, 54-67.

Sahin, A. (2010). Effects of jigsaw II technique on academic achievement and attitudes to written expression course. Educational Research and Reviews, Vol 5 No 12 , pp. 777-787.

Sangrà, A., \& González-Sanmamed, M. (2010). The role of information and communication technologies in improving teaching and learning processes in primary and secondary schools. ALT-J Research in Learning Technology, Volume 18, Number 3 , 207-220.

Schunk, D. H. (1991). Self-Efficacy and Academic Motivation. Educational Psychologist, Vol 26, Issue 3-4, 207-231.

Surya, Y. (2010, September 1). Pembelajaran IPA dan Matematika serta masalahnya. $\begin{array}{llll}\text { Retrieved March 2012, from } & \text { 3, }\end{array}$ http://www.yohanessurya.com/news.php?pid=101\&id=128

Tuominen, K., Savolainen, R., \& Talja, S. (2005). Information Literacy as A Sociotechnical Practice. Library Quarterly, vol. 75, no. 3, 329-345.

Weiner, B. (1972). Attribution Theory, Achievement Motivation, and the Educational Process. Review of Educational Research, Vol. 42, No. 2, 203-215.

Wyk, M. M. (2012). The Effects of the STAD-Cooperative Learning Method on Student Achievement, Attitude and Motivation in Economics Education. Journal of Social Science, Vol 33 No 2, 261-270.

Zimmerman, B. J. (2000). Self-Efficacy: An Essential Motive to Learn. Contemporary Educational Psychology $25,82-91$. 